only to contract the virus and die. The woman's pain worsens and she goes into labour. Would you help? Or, to protect yourself, would you leave her squirming on the floor to deliver the baby herself?

As we explore in a News Feature on page 24, women and health workers in West Africa are facing decisions like these every day. It helps to explain how, as new infections of Ebola are finally being brought under control and the world's attention moves on, the outbreak's devastating impact on maternal health will linger for years.

Pregnant women are uniquely vulnerable to the effects of Ebola, and it is extremely difficult to distinguish the disease's symptoms from routine pregnancy complications. And those who care for these women take their lives in their hands: pregnancy and childbirth necessarily expose carers to potentially infectious bodily fluids. As a result, many doctors, nurses and clinics have refused to treat any pregnant woman who presents with symptoms that could mark her as having Ebola. The United Nations Population Fund (UNFPA) has estimated that the maternal mortality rate - the annual number of maternal deaths per 100,000 live births - may double as a result. And this is happening in countries that already had among the worst maternal-health records in the world.

Some health workers have been brave enough to continue caring for pregnant women during the Ebola epidemic. These include doctors with the medical-aid group Médecins Sans Frontières (Doctors Without Borders) who have devised innovative ways to treat these women and have opened clinics specifically to care for these most vulnerable patients.

Samuel Batty and Amadu Jawara, two Sierra Leonean community health workers, have also stepped up. Both were assigned to work at a hospital in Freetown. When many nurses and doctors abandoned their posts, Batty and Jawara did not.

In November, Batty and Jawara assisted a pregnant woman with a fever. They gave her medication and her fever improved. Assuming that she had malaria, Batty examined her using no special Ebola precautions. It was a fatal mistake. Soon after, Batty himself died of the disease. Even after seeing his friend die, Jawara has continued to care for patients, knowing that they have nowhere else to turn. He estimates that he has performed 100 Caesarean sections.

Community health workers would not usually perform such a procedure. Both Batty and Jawara were trained in surgical skills through a programme run by the Norwegian non-governmental organization CapaCare in conjunction with the Sierra Leonean health ministry. The programme exemplifies an approach called surgical
"Pregnant women are uniquely vulnerable to the effects of Ebola." task-shifting, which attempts to redress the dearth of medical personnel in countries such as Sierra Leone by training health workers to give lifesaving care that might otherwise be unavailable to patients in under-resourced areas. CapaCare estimates that, by August 2014, approximately half the surgical procedures performed by its students were emergency obstetric procedures.

There is debate over the ethics of task-shifting: some worry that it risks exposing patients to substandard care. But the epidemic shows that the people trained by CapaCare are extraordinarily committed to their patients. In this setting, many people faced a choice of being cared for by Jawara, Batty and their counterparts or receiving no care at all.

Sierra Leone had only seven obstetricians before the outbreak began. The UNFPA is seeking US $\$ 56$ million to fund a new initiative to reopen health services for pregnant women and to recruit more than 500 midwives, doctors and health workers across the outbreak region. International donors should support this initiative.

Training more doctors and finding ways to incentivize them to stay in West Africa are priorities to help the region replace health workers who have lost their lives fighting the epidemic, and task-shifting has proved that it can be part of the solution. The CapaCare programme is currently on hold as a result of the deaths of Batty and another trainee. Restarting medical programmes, including ones such as this, are crucial as the region fights to end the outbreak and begin the long recovery process.

\section{Hues and cry}

\section{A blue dress divided the Internet - and put the science of visual perception in the spotlight.}

\section{$\mathrm{T}$} he influence on science and the arts of Johann Wolfgang von Goethe - poet, playwright, novelist, proto-scientist, philosopher and general all-round egghead - is profound. His views about the physiological nature of colours, however, have never really caught on, in part because he proposed that colours are more an invention of the mind than a physical reality. One thing, however, rings true: the appearance of objects is not objective, but a conversation between the observer and observed.

Neuroscientists have long recognized that the perception of colour and shade depends strongly on context. Illusions exist, for example, in which one can be utterly convinced that black is white, depending on the surrounding patterns or the conditions in which an object is lit. But it is also true that all other things being equal, the perception of colour differs between people.

One editor of this journal, for example, once owned a car that was, in his opinion, quite clearly green. It remained green in all conceivable circumstances of context, shade and illumination other than complete darkness. Except, however, that everyone else was equally convinced that it was blue - including the vehicle-licensing authority. The car was not only blue - it was officially blue.

Last week, the Internet was deluged with strongly held opinion about colour, specifically of a dress. The dress was advertised as being blue and black. But if illuminated in a certain way, the dress appeared white and gold. People were absolutely convinced of its colour combination, one way or the other. The web exploded with chromatic debate after various celebrities bruited their opinions on Twitter. A straw poll of Nature's editors (including the owner of the blue car) was roughly split down the middle, and convictions were strong - one way or the other.

The explanation for the illusion lies in the colour of the light in which the dress was photographed. The brains of people who read the overall ambience as too blue will overcompensate, seeing the dress as white and gold. Others, whose visual systems read that the lighting was not blue enough, saw the dress as blue and black.

Wired magazine hosted a full discussion on the effect (see go.nature. com/uqf7bo), and the consternation in that publication's office seemed to reflect the brouhaha that briefly reigned in the otherwise serene halls of Nature. (The wheels of this international weekly journal of science briefly ground to a halt as so: "I can't read any more manuscripts until I find out WHY?!”)

On being told of the illusion, some people - but not all — could just about force themselves to see the dress as black and blue rather than white and gold. The picture is a clear demonstration that colour perception varies between individuals, and according to the conditions of illumination. Such perception is distinct from the genetic conditions that predispose people to the various syndromes known as colour blindness.

Had the ghost of Goethe been watching 'dressgate', he might have allowed himself a rueful smile, given the brickbats thrown in his $\rightarrow$ NATURE.COM To comment online, click on Editorials at: go.nature.com/xhunqv direction by his scientific critics even in his own time, who, he said, "forgot that science arose from poetry, and did not see that when times change the two can meet again on a higher level as friends." 